\title{
The identification of Late Holocene bog bursts at Littleton bog, Ireland: ecohydrological changes display complex climatic and non-climatic drivers
}

Article

Accepted Version

Stastney, P., Young, D. S. and Branch, N. P. (2018) The identification of Late Holocene bog bursts at Littleton bog, Ireland: ecohydrological changes display complex climatic and non-climatic drivers. The Holocene, 28 (4). pp. 570-582. ISSN 0959-6836 doi: https://doi.org/10.1177/0959683617735581 Available at https://centaur.reading.ac.uk/72056/

It is advisable to refer to the publisher's version if you intend to cite from the work. See Guidance on citing.

To link to this article DOI: http://dx.doi.org/10.1177/0959683617735581

Publisher: Sage Publications

All outputs in CentAUR are protected by Intellectual Property Rights law, including copyright law. Copyright and IPR is retained by the creators or other copyright holders. Terms and conditions for use of this material are defined in the End User Agreement. 


\section{CentAUR}

Central Archive at the University of Reading

Reading's research outputs online 
The identification of Late Holocene bog bursts at Littleton bog, Ireland: ecohydrological changes display complex climatic and non-climatic drivers

Phil Stastney (corresponding author) - Department of Archaeology, University of Reading, Reading, UK. RG6 6AB. p.stastney@reading.ac.uk +44 (0)118 378 6801

Daniel Stuart Young - QUEST, School of Archaeology Geography and Environmental Science, University of Reading, Reading, UK. RG6 6AB. d.s.young@reading.ac.uk +44 (0)118378 7978

Nicholas Philip Branch - School of Archaeology Geography and Environmental Science, University of Reading, Reading, UK.

n.p.branch@reading.ac.uk +44 (0)118 3786102 


\section{Abstract}

In order to clearly understand the response of raised mires to past climate change, it is important to consider the full range of drivers and responses of these ecohydrological archives. To this end, a high resolution ecohydrological record from Littleton bog, Co. Tipperary, Ireland, was generated utilizing a combination of plant macrofossils, testate amoebae, and humification analysis.

Chronological control for this record was provided by a Bayesian age-depth model based on AMS radiocarbon dates. Testate amoebae-derived reconstructed peatland water tables indicate a series of sudden shifts to dry bog surface conditions at $c .3140, c .2510$, and $c .1540$ cal BP. These events display a distinctive palaeoecological signal and chronological tempo that is best explained as a result of a series of bog burst events, and which seem inconsistent with other explanations. The chronological correspondence between the bog bursts at Littleton and a set of similar events at Derryville bog, $c .5 \mathrm{~km}$ to the north, is noted, as is the broad correspondence of these events with wet-shifts indicated in regional peatland water table compilations from Britain and Ireland. A range of possible driving mechanisms for these events is proposed, including anthropogenic disturbance of the bog surface, non-linear response to climate forcing, internal bog dynamics, vegetation succession, or a 
combination of factors. We illustrate the need for further multi-proxy investigations to fully understand these phenomena.

\section{Key words}

palaeohydrology, Sphagnum austinii, bog bursts, testate amoebae, Ireland, Late Holocene

\section{Introduction}

Since Barber's (1981) falsification of the cyclic model of peat bog growth, raised mires have been recognized as important archives of Holocene environmental change (Barber and Charman 2003; Charman 2010; Swindles et al. 2013). As a result of its oceanic climate that is strongly influenced by the North Atlantic Drift and variability in Westerly airflow, Ireland has been identified as a key region for Holocene palaeoclimatic studies (Lehman and Keigwin 1992; Swindles et al. 2013). Irish peatland palaeohydrological records have provided evidence for regional climatic teleconnections (Barber et al. 2000; Swindles et al. 2010; Langdon et al. 2013) revealing centennial-scale climatic variability 
during the mid- to late-Holocene (Swindles et al. 2013) and allowing the examination of discrete climatic 'events' at 5.2ka (Roland et al. 2015), 4.2ka (Roland et al. 2014) and 2.8ka (Plunkett 2006; Swindles et al. 2007) that have been identified in records in other regions and at the hemispheric to global scale (Van Geel et al. 1996; Bond et al. 2001; Barber et al. 2004; Mayewski et al. 2004).

Recently the complexities of the peatland palaeohydrological record have become increasingly apparent. When examined in detail, regional coherence between records has often been found to be unclear (Blackford 2000; Payne and Blackford 2008; Swindles et al. 2013). At least some of this inconsistency can be attributed to complexities in proxy-environment responses (e.g. Mauquoy and Barber 1999a; Caseldine and Gearey 2005; Yeloff and Mauquoy 2006; Swindles and Roe 2007), imprecision in statistical reconstruction methods (Telford and Birks 2005, 2011a, 2011b) and, above all, chronological uncertainties (Baillie 1991; Plunkett 2006; Blaauw et al. 2007; Blaauw 2012). It is nevertheless apparent that the peatland palaeohydrological record is typically 'noisy' and may not reflect a 'pure' palaeoclimatic signal, but one that is modulated both by localized variability and internal, autogenic, feedback mechanisms (Morris et al. 2011, 2015; Swindles et al. 2012), and, in some cases, also potentially human impact (Casparie 2001; Turner et al. 2014). 
In addition to the complexities inherent in the peatland palaeohydrological record itself, other poorly-understood phenomena such as bog bursts provide a further, and currently unquantified, source of uncertainty. Bog bursts are defined as catastrophic mass movements in the surface of a raised mire resulting in the outflow of saturated peat and the lowering of the water table (Dykes and Warburton 2007). Since 1900, over 50 bog burst events have been recorded in Ireland (Kiely et al. 2010), although most of these recent events have occurred in blanket peatlands (Feehan and O'Donovan 1996, 399-401) and would therefore mostly be classified as 'bogflows' or 'bog slides' rather than 'bog bursts' sensu Dykes and Warburton (2007). Nevertheless, there are contemporary eyewitness accounts of bog bursts in lowland raised bogs during the historic period, for example at Kilmaleady (Woodfield bog), Co. Offaly, in 1821 (Feehan and O'Donovan 1996, 402; Tallis 2001, 219-20).

In palaeoenvironmental records, these events are typically identified through the presence of erosional features, reversals in peat age-depth relationships, and sudden dry shifts in BSW records. At present, there are only a few palaeoenvironmental records that unambiguously show bog bursts including sites in the Netherlands (e.g. Van Geel et al. 2014), Tumbeagh bog, Co. Offaly (Casparie 2006), and Derryville bog, Co. Tipperary (Caseldine and Gearey 2005). It has been suggested that bog bursts might have been a relatively 
common phenomenon associated with the normal development of raised bogs in Ireland (Casparie 2005, 25), however the evidence for this in the palaeoenvironmental record is sparse. Part of the reason for this may be the inherent difficulty in conclusively identifying such events in peat sequences: those studies which have identified these events have done so based on widespread mapping of peat stratigraphy (including in section) and the analysis of multiple peat sequences from the same site. Such detailed and timeconsuming studies - which have generally been driven by wetland archaeological rather than purely palaeoecological research questions - are unsurprisingly rare, and therefore at present it is not only difficult to determine how widespread such events were, but the drivers and palaeoecological consequences of bog bursts are still not fully understood.

These uncertainties highlight the importance of both a multi-proxy approach to palaeohydrological reconstruction, and the consideration of records from multiple sites to fully investigate these complexities. To this end a palaeohydrological record from a site in central Ireland is presented, displaying just such a range of complex forcing mechanisms and palaeohydrological responses reflected in multiple palaeohydrological proxies.

\section{Site}


[Insert Figure 1]

Littleton bog is a milled peat production bog, and former raised bog, located c. $8 \mathrm{~km}$ east of Thurles, Co. Tipperary, Ireland $\left(52^{\circ} 41^{\prime} 56 " \mathrm{~N}, 7^{\circ} 39^{\prime} 40 " \mathrm{~W}\right.$, altitude: 125m O.D., $300 \mathrm{ha}$ in area), see Figure 1. The solid geology of the area consists of Carboniferous limestone overlain by superficial deposits of Glacial till (diamict). The site, which measures $c .2 \mathrm{~km}$ from N-S and $1 \mathrm{~km} \mathrm{E-W,} \mathrm{forms} \mathrm{part}$ of a larger chain of peatlands lying within a possible glacial valley or tongue basin stretching for $40 \mathrm{~km}$ between the Slieve Bloom mountains in the north, to the Slieveardagh Hills and Cashel in the south (Casparie and Gowen 2005). At Gurteen, Co. Offaly, $50 \mathrm{~km}$ north of the site, mean annual rainfall of $948.2 \mathrm{~mm}$ and mean temperature of $9.8^{\circ} \mathrm{C}$ were recorded for the period 1981-2010 (Met Éireann 2012).

The Littleton group of bogs is notable for palynological work carried out in the mid -20th century by Mitchell $(1956,1965)$. This work defined the main phases of recent vegetation history, with Littleton recognized as the type site for the Holocene in Ireland - the 'Littletonian' in older literature (Mitchell 1981).

Archaeological investigations at Littleton bog, carried out between 2006 and 2008, revealed more than 30 archaeological features, mainly wooden trackways and 'platform' structures, dating from between c.3500-1600 cal BP, i.e. Early 
Bronze to Iron Age (Whitaker 2006; Turrell 2008). Similarly, other former raised bogs in the vicinity of the site have been subject to archaeological study in advance of industrial peat harvesting and mineral extraction, revealing a similar pattern of widespread past human activity (Gowen et al. 2005; National Monuments Service 2013).

\section{Methods}

A transect of six boreholes (BH4 to $\mathrm{BH} 9$ ), at 100m spacing, was put down using a 'Russian' peat sampler between two NNW-SSE-aligned drainage ditches. In order to avoid areas of direct anthropogenic disturbance, boreholes were situated a minimum of 50m away from the conjectured alignment of any known archaeological structures. The peat stratigraphy was described in the field using standard criteria (Troels-Smith 1955; Kershaw 1997), and the location with the deepest and most representative ombrotrophic peat sequence was selected for re-sampling to recover peat cores for laboratory analysis.

Ten samples of picked and cleaned aerial plant remains for AMS 14C dating were taken from the core between $26 \mathrm{~cm}$ and $369 \mathrm{~cm}$ below ground level $(\mathrm{bgl})$. Nine samples consisted of stems or branches of Sphagnum spp. and one of stems of Eriophorum sp. Dates were calibrated using the IntCal13 calibration curve (Reimer et al. 2013) in the Bacon v.2.2 software package (Blaauw and 
Christen 2011) that runs in the R statistical environment (R Core Team 2013). A Bayesian age-depth model was then developed using Bacon which generated $95 \%$ confidence intervals and weighted mean age estimates at $1 \mathrm{~cm}$ intervals along the core through several million MCMC iterations (Blaauw and Christen 2011). In the following text, dates prefixed by ' $C$ ' are weighted mean values from the Bacon age-depth model, rounded to nearest ten years.

The upper $250 \mathrm{~cm}$ of $\mathrm{BH} 6$ was subsampled at $4 \mathrm{~cm}$ intervals for colorimetric humification analysis. Subsamples of $\sim 4 \mathrm{~cm}^{3}$ were prepared using standard methods (Blackford and Chambers 1993; Chambers et al. 2010) and the percentage light absorbance at 540nm was measured.

Subsamples for plant macrofossil analysis were taken at $4 \mathrm{~cm}$ intervals through the uppermost $250 \mathrm{~cm}$ of $\mathrm{BH} 6$. Subsamples of $4 \mathrm{~cm}^{3}$ volume were analyzed using the quadrat and leaf count (QLC) method developed by Barber et al. (1994): proportions of peat components were estimated under x10 magnification, and a random selection of Sphagnum leaves (>100 per sample) were identified at $x 400$ magnification to the lowest possible taxonomic level. Identifications were made using the University of Reading reference collection and published sources (Hill 1976; Hill et al. 1992; Mauquoy and van Geel 2007). Detrended Correspondence Analysis (DCA) was carried out on the plant macrofossil data, following the methods of Barber et al. (1994), with rare taxa 
removed, and values for all variables (including identified Sphagnum taxa) calculated as a percentage of the total peat matrix in each sample. Additionally, a variant of the Dupont (1986) Hydrological Index (DHI) with additional taxa scores from Mauquoy et al. (2008) and Daley and Barber (2012) was applied to the macrofossil data from the ombrotrophic part of the sequence only.

Subsamples for testate amoebae analysis were taken at $2 \mathrm{~cm}$ intervals through the uppermost $250 \mathrm{~cm}$ of $\mathrm{BH} 6$. Subsamples of $1 \mathrm{~cm}^{3}$ volume and $1 \mathrm{~cm}$ stratigraphic thickness were prepared following standard methods (Charman et al. 2000, Booth et al. 2010).Samples were mounted in distilled water and examined at magnifications of between x200 and x1000 until counts of 50-150 tests were reached; samples with fewer than 50 tests were excluded from further analysis. Test identifications were made using published guides (Corbet 1973; Ogden and Hedley 1981; Charman et al. 2000) and followed the taxonomy of Charman et al. (2000) except that Amphitrema flavum is placed in the genus Archerella (Gomaa et al. 2013). Quantitative reconstructions of BSW, expressed as depth to water table (DWT), were obtained using the panEuropean transfer function of Amesbury et al. (2016), with sample-specific errors generated using 1000 bootstrap cycles (Line et al. 1994).

\section{Peat stratigraphy and chronology}


[Insert Figure 2]

Figure 2 shows a stratigraphic cross-section across the site based on the borehole transect. The present surface profile of the bog is slightly concave due to drainage, peat removal, and subsequent shrinkage and compression of the peat; nevertheless, in the center of the basin $(\mathrm{BH} 5-7)$ up to $500 \mathrm{~cm}$ of peat was recorded. Detrital lake sediments were encountered at the base of the peat sequence within the center of the basin, with clastic mineral sediments beneath the peat at the edges. The basal lacustrine and minerogenic strata were overlain by up to $3-4 \mathrm{~m}$ of predominantly herbaceous, and occasionally woody, humified fen peat. Sphagnum-rich ombrotrophic peat of varying humification, up to $170 \mathrm{~cm}$ thick in $\mathrm{BH} 6$, caps the sequence. In $\mathrm{BH} 6$ there is a transition from well-humified herbaceous peat to well-humified Sphagnum-EriophorumEricaceae peat at $170 \mathrm{~cm} \mathrm{bgl,} \mathrm{followed} \mathrm{by} \mathrm{a} \mathrm{further} \mathrm{transition} \mathrm{to} \mathrm{generally} \mathrm{less-}$ humified Sphagnum-rich peat at $100 \mathrm{~cm}$ bgl. The top $18 \mathrm{~cm}$ of the sequence was composed of desiccated and disturbed peat that is thought to have been redeposited by peat harvesting machinery.

Results of the AMS ${ }^{14} \mathrm{C}$ dating of the sequence are given in Table 1, and the age-depth model is presented in Figure 3. Peat accumulation in $\mathrm{BH} 6$ began before $7500-7330$ cal BP, whilst the top of the sequence dates to the modern period, indicating that relatively little peat, if any, has been removed from this 
part of the bog. The dates indicate an overall peat accumulation rate of $\sim 21 \mathrm{yr}$ $\mathrm{cm}^{-1}$ although this varies between $\sim 24 \mathrm{yr} \mathrm{cm}^{-1}$ in the lower part of the sequence (369-167 $\mathrm{cm} \mathrm{bgl)} \mathrm{to} \sim 17 \mathrm{yr} \mathrm{cm}^{-1}$ in the upper part $(167-26 \mathrm{~cm} \mathrm{bgl)}$. Two inversions in the expected age-depth relationship were noted: between $240 \mathrm{~cm}$ (LLNL164207) and 202cm bgl (BETA-304237); and between 98cm (BETA-304236) and $86 \mathrm{~cm}$ bgl (OxA-32928). Although the latter inversion is relatively minor and may be attributed to statistical scatter, the inversion at $240-202 \mathrm{~cm}$ bgl is more notable, and BETA-304237 (202cm bgl) is identified as an outlier by the agedepth model, potentially indicating the redeposition of older material within this part of the peat sequence, perhaps due to root penetration.

[Insert Figure 3]

Table 1: $\mathrm{AMS}{ }^{14} \mathrm{C}$ dates from $\mathrm{BH} 6$, Littleton bog.

\begin{tabular}{llllll}
$\begin{array}{l}\text { Depth } \\
\text { (cm) }\end{array}$ & Lab code & $\begin{array}{l}\text { Material } \\
\text { dated }\end{array}$ & $\mathbf{\delta}^{13} \mathbf{C}$ & $\begin{array}{l}\text { Conventional } \\
\text { age (BP) }\end{array}$ & $\begin{array}{l}95 \% \\
\text { calibrated } \\
\text { range (cal } \\
\text { BP) }\end{array}$ \\
\hline 26 & OxA-32927 & Sphagnum & -26.5 & $135 \pm 25$ & $270-10$ \\
42 & OxA-33794 & Sphagnum & -26.9 & $450 \pm 27$ & $530-480$ \\
50 & $\begin{array}{l}\text { BETA- } \\
\text { 304235 }\end{array}$ & Sphagnum & -24.3 & $820 \pm 30$ & $780-690$ \\
86 & OxA-32928 & Sphagnum & -25.2 & $1318 \pm 26$ & $1290-1180$ \\
98 & $\begin{array}{l}\text { BETA- } \\
\text { 304236 }\end{array}$ & Sphagnum & -25.1 & $1070 \pm 30$ & $1050-930$ \\
146 & BETA- & Sphagnum & -24.6 & $2370 \pm 40$ & $2680-2330$
\end{tabular}


261636

$\begin{array}{llllll}167 & \begin{array}{l}\text { LLNL- } \\ 164206\end{array} & \text { Sphagnum } & -25.0 & 2400 \pm 60 & 2700-2340 \\ 202 & \begin{array}{l}\text { BETA- } \\ 304237\end{array} & \text { Eriophorum } & -26.9 & 4670 \pm 40 & 5570-5310 \\ 240 & \begin{array}{l}\text { LLNL- } \\ 164207\end{array} & \text { Sphagnum } & -25.0 & 3625 \pm 30 & 4070-3850 \\ 369 & \begin{array}{l}\text { BETA- } \\ \text { BE1637 }\end{array} & \text { Sphagnum } & -26.6 & 6520 \pm 40 & 7500-7330\end{array}$

\section{Plant macrofossil analysis}

[Insert Figure 4]

The results of the plant macrofossil analysis of the upper $250 \mathrm{~cm}$ of $\mathrm{BH} 6$ are presented in Figure 4. The diagram has been subjectively divided into plant macrofossil assemblage zones (PM-LTN1 to PM-LTN6) which reflect changes in the degree of mire surface wetness based on the ecology of mire flora sensu Mauquoy and Barber (1999a). The plant macrofossil assemblage shows a variety of taxa and associated niches, indicating that the sensitivity of the mire to BSW changes is not limited by the presence of single eurytypic taxa (e.g. Sphagnum fuscum) (Barber et al. 1994).

PM-LTN1, 250-210cm bgl, c.4140-3470 cal BP 
Zone PM-LTN1 is dominated by Eriophorum sp. (c.f. vaginatum) with abundant undifferentiated monocots, occasional Ericaceous remains and high proportions of decomposed unidentifiable organic material $<125 \mu \mathrm{m}$ (UOM). Very low percentages of Sphagnum spp. are recorded, but these include $S$. sect. Acutifolia, S. sect. Cuspidata, S. papillosum and S. austinii. In general this zone is indicative of base-poor, relatively dry, bog surface conditions with no evidence for the mesotrophic fen taxa seen in the subsequent zone PM-LTN2 (below).

PM-LTN2, 210-170cm bgl, c.3470-2690 cal BP

This zone is dominated by remains of Carex sp. and, in the lower part of the zone, Phragmites australis, indicative of a fen intermittently or permanently flooded with shallow or still water (Haslam 1972). Carex sp. (including C. limosa and C. rostrata) occur in mesotrophic and poor fens, although $C$. limosa can also be found in pools in ombrotrophic bogs (Mauquoy and van Geel 2007). The absence of Sphagnum in this zone is indicative of peat accumulation in a mesotrophic/base-poor fen.

PM-LTN3, $170-100 \mathrm{~cm}$ bgl, c.2690-1320 cal BP

PM-LTN3 is dominated by Sphagnum spp. (predominantly S. sect. Acutifolia with some S. papillosum, S. sect. Cuspidata and S. austinii), Eriophorum sp. 
(c.f. vaginatum), Ericaceae and undifferentiated monocots. The abundance of Sphagnum and Eriophorum in this zone is indicative of a transition to ombrotrophic conditions, suggesting that the fen-bog transition (FBT) occurs at c. $170 \mathrm{~cm}$ bgl. The pioneer raised mire flora in this zone is indicative of a relatively dry bog surface, the dominant component of the Sphagnum community being S. sect. Acutifolia. Sphagnum species within this section are difficult to differentiate, and can occupy a range of microforms from high hummocks to lawns (Mauquoy and van Geel 2007); however their presence in the $\mathrm{BH} 6$ assemblage appears to correlate well with more humified peat containing increased abundances of UOM and Ericaceous remains. Zone PMLTN3 is therefore considered to indicate an assemblage typical of drier bog surface conditions, comparable to the Acutifolium or Acutifolia-Cymbifolium communities defined by McMullen et al. (2004), thought to indicate water table depths of between 2 and $15 \mathrm{~cm}$. This interpretation is supported by the presence of Scirpus cespitosus at the base of this zone, which is typically found on drier areas of raised bogs (Mauquoy and van Geel 2007).

PM-LTN4, $100-50 \mathrm{~cm} \mathrm{bgl,} \mathrm{c.1320-730} \mathrm{cal} \mathrm{BP}$

PM-LTN4 is dominated by Sphagnum austinii and S. papillosum. S. papillosum is dominant at the base of the zone, indicative of relatively wet conditions since it grows on low lawn microforms (Mauquoy and van Geel 2007). For the 
remainder of the zone $S$. austinii is dominant; this taxon has occupied a range of microforms in the past, from low lawns to hummocks (Hill 1988). However, studies have demonstrated the ability of $S$. austinii to grow in abundance in relatively dry ombrotrophic bogs (Mauquoy and van Geel 2007), and a compact, hummock-building form is currently particularly characteristic of the oceanic NW seaboard of Europe (Daniels and Eddy 1985). The relatively high percentages of both S. austinii and S. papillosum are perhaps indicative of moderately wet conditions throughout this zone.

PM-LTN5, 50-29cm bgl, c.730-230 cal BP

Sphagnum sect. Acutifolia dominates zone PM-LTN5, along with high percentages of undifferentiated monocots, Ericaceous remains and UOM. As discussed above, the dominance of $S$. sect. Acutifolia in conjunction with high proportions of Ericaceous remains and UOM is interpreted to be indicative of dry BSW conditions.

PM-LTN6, 29-18cm bgl, after c.230 cal BP

This zone is dominated by Sphagnum papillosum, indicative of wetter conditions on the bog surface (Mauquoy and van Geel 2007).

Statistical analysis of plant macrofossil data 
DCA axis 1 (eigenvalue 0.6395 ) appears to represent a hydrological gradient: taxa indicative of wet conditions (Sphagnum papillosum and S. sect. Cuspidata) have high axis 1 scores, and low scores are recorded for drier indicators (e.g. Eriophorum sp., Ericaceae and S. sect. Acutifolia). However, it is notable that Sphagnum austinii has the highest axis 1 score, potentially suggesting an affinity with wetter conditions at the site.

DHI scores generally show good agreement with DCA axis 1 scores, especially in zones PM-LTN4 to PM-LTN6, although agreement between the two indices is less clear in PM-LTN3. DHI scores range from $\sim 700$ (indicating dry conditions) to 400 (wet). The DHI values indicate dry, but variable, BSW conditions in zone PM-LTN3, wet conditions in PM-LTN4 and PM-LTN6, punctuated by a shift towards drier conditions in PM-LTN5. DHI scores were not calculated for PM-LTN1 or PM-LTN2, as these assemblage zones are not interpreted as being definitely indicative of ombrotrophic conditions, and thus plant macrofossil assemblages are likely to reflect changes in trophic status as opposed to reflecting a BSW-dominated signal. Since subsequent discussion of these data will focus predominantly on the BSW signal from the site, DHI scores will be used for comparison with other proxy data.

\section{Testate amoebae analysis}


[Insert Figure 5]

The results of the testate amoebae analysis of the top $238 \mathrm{~cm}$ of $\mathrm{BH} 6$ are presented in Figure 5. Based on a visual assessment of the data, the diagram has been divided into testate amoebae assemblage zones (TA-LTN1 to TALTN12) which are summarized in Table 2. Test concentration, although generally high, was occasionally poor, and samples yielding counts of $<50$ tests were excluded from further analysis; this included all samples below $238 \mathrm{~cm}$ bgl and some samples in zone TA-LTN3. Although test counts in zone TA-LTN1 were generally high, samples in this zone displayed some of the lowest diversity index scores for the entire sequence; this may either be an indication of ecological stress (Magurran 1988) or, alternatively, the predominance of taxa only with relatively robust tests might be indicative of issues with differential preservation in this zone (Swindles and Roe 2007). A total of 34 taxa were encountered in the assemblages from $\mathrm{BH}$.

Table 2: Summary of testate amoebae assemblage zones. Calendar date ranges use the weighted mean values derived from the Bacon age-depth model.

\begin{tabular}{lllll} 
Zone & $\begin{array}{l}\text { Depth } \\
\text { (cm bgl) }\end{array}$ & $\begin{array}{l}\text { Date range } \\
\text { cal BP } \\
\text { (w. mean) }\end{array}$ & $\begin{array}{l}\text { Main taxa } \\
\text { (max \% in parenthesis) }\end{array}$ & Notes \\
\hline TA-LTN1 & $238-224$ & $3930-3700$ & Hyalosphenia subflava (98\%) & $\begin{array}{l}\text { Low } \\
\text { diversity }\end{array}$ \\
TA-LTN2 & $224-192$ & $3700-3140$ & $\begin{array}{l}\text { A. flavum (62\%), A. } \\
\text { wrightianum (45\%) }\end{array}$ &
\end{tabular}




\begin{tabular}{|c|c|c|c|}
\hline TA-LTN3 & $192-180$ & $3140-2900$ & $\begin{array}{l}\text { H. subflava }(29 \%), \text { A. } \\
\text { muscorum }(53 \%) \text {, Amphitrema } \\
\text { stenostoma }(19 \%)\end{array}$ \\
\hline TA-LTN4 & $180-157$ & $2900-2510$ & $\begin{array}{l}\text { A. flavum ( } 88 \%), A \text {. } \\
\text { wrightianum }(30 \%), A \text {. } \\
\text { muscorum }(25 \%)\end{array}$ \\
\hline TA-LTN5 & $157-149$ & $2510-2410$ & $\begin{array}{l}\text { H. subflava }(40 \%), A . \\
\text { muscorum }(36 \%)\end{array}$ \\
\hline TA-LTN6 & $149-137$ & $2410-2160$ & $\begin{array}{l}\text { A. flavum ( } 83 \%) \text {, Assulina spp. } \\
(20 \%) \text {, A. wrightianum }(11 \%)\end{array}$ \\
\hline TA-LTN7 & $137-120$ & $2160-1770$ & $\begin{array}{l}\text { A. flavum }(62 \%), A \text {. } \\
\text { wrightianum }(28 \%), H \text {. } \\
\text { subflava }(23 \%)\end{array}$ \\
\hline TA-LTN8 & $120-110$ & $1770-1540$ & $\begin{array}{l}\text { A. flavum }(83 \%), \text { A. } \\
\text { wrightianum }(20 \%) \text {, Arcella } \\
\text { discoides type }(20 \%)\end{array}$ \\
\hline TA-LTN9 & $110-96$ & $1540-1270$ & $\begin{array}{l}\text { H. subflava }(68 \%), A . \\
\text { muscorum }(15 \%)\end{array}$ \\
\hline TA-LTN10 & $96-48$ & $1270-680$ & $\begin{array}{l}\text { A. flavum (68\%), Difflugia } \\
\text { pulex }(43 \%) \text {, Amphitrema spp. } \\
(30 \%), \text { Assulina spp. }(29 \%)\end{array}$ \\
\hline TA-LTN11 & $48-34$ & $680-340$ & $\begin{array}{l}\text { A. flavum }(50 \%), \text { A. } \\
\text { wrightianum }(21 \%) \text {, Assulina } \\
\text { spp. }(18 \%), \text { A. discoides type } \\
(12 \%)\end{array}$ \\
\hline TA-LTN12 & $34-18$ & After 340 & $\begin{array}{l}\text { D. pulex }(57 \%) \text {, Cyclopyxis } \\
\text { arcelloides type (47\%), A. } \\
\text { flavum }(20 \%) \text {, Heleopera spp. } \\
(20 \%)\end{array}$ \\
\hline
\end{tabular}

Some low test counts 
DWT values reconstructed using the pan European transfer function of Amesbury et al. (2016) range from $-3.5 \mathrm{~cm}$ to $25 \mathrm{~cm}$ and have a mean value of $5.7 \mathrm{~cm}(\sigma=6.01)$ throughout the sequence from BH6. DWT values of $\sim 20 \mathrm{~cm}$ in TA-LTN1 indicate dry surface conditions, and are followed by a distinct shift towards wetter conditions in TA-LTN2. Generally wet to moderately-wet conditions are then punctuated by a series of sharp shifts to dry conditions (DWT values $>9 \mathrm{~cm}$ ) in TA-LTN3, TA-LTN5 and TA-LTN9. Wet conditions, with reconstructed water tables at, or near, the surface return in TA-LTN10, followed by variable BSW conditions in TA-LTN11 and TA-LTN12. Whilst absolute DWT values are shown in Figure 5, values were converted to standardized residual zscores, following the recommendations of Amesbury et al. (2016), in order to facilitate comparison with other records in the following discussion section.

\section{Discussion}

[Insert Figure 6]

The central box in Figure 6 shows summaries of the three palaeohydrological proxies from BH6: plant macrofossil DHI scores, standardized humification values, and testate amoebae-derived DWT z-scores (Amesbury et al. 2016) plotted against weighted mean age estimates from the age-depth model. 
Visual assessment of the three palaeohydrological proxies from $\mathrm{BH} 6$ shows limited overall agreement in the period between c.4100-1300 cal BP. Humification values show moderate variability, but few obvious trends and little clear agreement with testate amoebae-derived DWT z-scores; although plant macrofossil-derived DHI scores (only calculated for assemblages indicative of ombrotrophic conditions, from c.2700 cal BP onwards) do appear to show some agreement with the humification data after $c .2000$ cal BP. Between $c .4100-2700$ cal BP plant macrofossils indicate changes in trophic status at the sampling location: oligotrophic conditions are indicated between c.4100-3470 cal BP, followed by a switch to assemblages characteristic of more mesotrophic conditions occurring at $3750-3160$ cal BP $(95 \%$ confidence, weighted mean $=$ 3470 cal BP). This may indicate a complex pathway towards ombrotrophic conditions (sensu Hughes and Barber 2004) at Littleton: earlier development towards ombrotrophic conditions before $c .4100$ was followed by a reversion to a mesotrophic fen environment prior to the final (re)establishment of fully ombrotrophic conditions at 2840-2470 cal BP (95\% confidence, weighted mean $=2700 \mathrm{cal}$ BP). Widely fluctuating water tables indicated at the beginning of the record, between c.4100-3700 cal BP, may be an artefact of variable test preservation or the changes in trophic status indicated by the plant macrofossil 
assemblages, or both (Payne 2010), and should therefore be regarded with caution.

The period from c.3700-1300 cal BP was characterized by somewhat variable but moderately wet conditions punctuated by a series of sudden and drastic falls in water table (DWT z-scores $>0.6$ ); these events, indicated by the onset of assemblage zones TA-LTN3, TA-LTN5 and TA-LTN9 which are characterized by testate amoebae assemblages strongly dominated by Hyalosphenia subflava, are labelled A, B and C on Figure 6. The onset of events A, B and C are dated to $3440-2850 \mathrm{cal}$ BP $(95 \%$ confidence, weighted mean $=3140 \mathrm{cal}$ BP), $2640-2301$ cal BP (95\% confidence, weighted mean $=2510 \mathrm{cal} \mathrm{BP})$, and 1830-1290 cal BP (95\% confidence, weighted mean $=1540$ cal BP), respectively. Macrofossil assemblages during this period were generally dominated by monocotyledons reflected in geberally high $\mathrm{DHI}$ scores; meanwhile, humification values were high but variable. An identical situation was noted by Caseldine and Gearey (2005, p.598) who suggested that such monocot-dominated communities may be tolerant of (and therefore potentially insensitive to) shifts towards dry BSW conditions. The interpretation of these events is discussed below.

At $1572-1150$ cal BP $(95 \%$ confidence, weighted mean $=1300 \mathrm{cal} \mathrm{BP})$ all three proxies indicate a consistent shift towards wetter conditions, which persist, with 
some variability reflected in all three proxies, until at least $c .750$ cal BP when DHI scores increase, lagging slightly behind an increase in humification values. This shift towards drier BSW conditions indicated by the plant macrofossil and humification data is not immediately reflected by DWT z-scores, although DWT does increase later. Between c.580-420 cal BP all three proxies indicate moderately dry BSW conditions, followed by a wet-shift reflected in falling DWT and humification values and a lagged fall in DHI scores after c.250 cal BP. After c.250 cal BP, DWT values are variable but show increases not reflected in the plant macrofossil or humification data.

\section{Evidence for bog bursts at Littleton Bog}

As discussed above, the most striking feature of the testate amoebae data in the lower part of the sequence from Littleton (below $\sim 100 \mathrm{~cm}$ bgl, before $c .1300$ cal BP) is a series of sudden and sharp increases in DWT values (shifts to dry conditions), labelled A, B and C on Figure 6. These events are most obvious in the testate amoebae data but are associated with broadly consistent floristic assemblages and display a distinctive chronological tempo. The defining characteristics of these events are:

- Sudden and sharp increases in the abundance of testate amoebae taxa indicative of dry conditions, most notably Hyalosphenia subflava followed 
by a return to dominance of wet-indicators (Archerella flavum, Amphitrema spp. etc.) reflecting a recovery in the peatland water table after an interval of up to a few centuries. The age-depth model suggests that the re-establishment of wet conditions occurred after intervals of 0 799yrs (based on the full range of the $95 \%$ confidence intervals), with weighted mean estimates for the duration of dry conditions of 242yrs, 105yrs, and 263yrs for event A, B and C, respectively.

- Plant macrofossil communities dominated by monocots with high (>20\%) abundances of UOM. Remains of other taxa are typically present in only low abundances, and often decline at the onset of the events. Sphagnum, where present, is typically dominated by sect. Acutifolia.

- Generally high standardized humification values (>0.6 SD units for events $A$ and $C$, event $B$ displays values of $>0.4$ followed by a lagged increase).

- Repeated events with multicentennial to millennial return times (from the onset of one event - defined by the sudden increase in $H$. subflava - to the onset of the following event). Based on the full $95 \%$ confidence intervals of the age-depth model, the minimum gap between events is 197yrs (between events $A$ and $B$, gap in weighted mean estimates = 
$630 \mathrm{yrs}$ ) and the maximum is 1358yrs (event B to event $\mathrm{C}$, weighted mean estimate $=975 \mathrm{yrs}$ ).

- Generally slower weighted mean peat accumulation rates - the section of the sequence in which the events occur $(192-96 \mathrm{~cm}$ bgl) has a mean accumulation rate of $19 \mathrm{yr} \mathrm{cm}^{-1}$, compared with $16 \mathrm{yr} \mathrm{cm}^{1}$ between $96-$ $26 \mathrm{~cm}$ bgl.

Whilst it is clear that these events represent repeated episodes of sudden drying and subsequent re-wetting of the bog surface, the reasons for these hydrological shifts is not clear. Five plausible explanations, which will be assessed in turn below, are:

i. A series of sudden and severe droughts.

ii. Direct human impact - artificial drainage of the bog, or peat cutting.

iii. Bog bursts at a distant site elsewhere in the Littleton bog complex.

iv. Bog bursts at Littleton bog.

v. Some other unexplained, and as yet untheorized, mechanism.

i) Drought - Given that there is evidence to suggest that the BSW record is driven by summer precipitation deficit (Charman et al. 2009), the hypothesis that the dry shifts were caused by repeated droughts is theoretically reasonable. The magnitude and duration of the dry shifts indicated by the testate amoebae 
would, however, require a series of extremely sudden large-magnitude droughts lasting a century or more which would be expected to be clearly visible in other proxy reconstructions; regional BSW reconstructions (see section below) do not show any evidence for such droughts. Therefore, this explanation is regarded as unlikely.

ii) Drainage or peat cutting - This hypothesis is difficult to test due to a lack of evidence, both from Littleton bog itself, as well as a general lack of evidence for or against direct human impacts on raised mires in prehistory. The archaeological evidence from Littleton clearly demonstrates that people were active in and around the site at around the times of the drying events, and activities such as localized peat cutting or drainage of the bog surface could indeed account for the sudden onset and large magnitude of the drying indicated by DWT values. Whilst human exploitation of the bog, for example through peat cutting, might well be expected to produce a pattern of repeated signals, the long gaps between events - at least 197yrs, perhaps more likely $>600 \mathrm{yrs}$, and therefore spanning several generations - is not especially consistent with a pattern of sustained economic or cultural activity by local groups. Although difficult to test outright, there is insufficient evidence to support the hypothesis that prehistoric drainage or peat cutting occurred at Littleton and could account for the drying events. 
iii) Bog bursts at another site in the Littleton bog complex: Derryville bog - One of the few sites in Ireland where prehistoric bog bursts have been positively identified is the site of Derrville bog, Co. Tipperary (Caseldine and Gearey 2005). Derryville bog is less than $5 \mathrm{~km}$ to the north of Littleton bog and is part of the same hydrologically-connected complex of wetlands; it is therefore plausible that the variations in the DWT curve observed at Littleton could be caused by the bog bursts at Derryville rather than by more local events. Bog bursts at Derryville were dated to $c .3200$ and c.2550, with a further possible burst at 1400 cal BP (Caseldine and Gearey 2005), and are therefore consistent, within the $95 \%$ confidence intervals, with the dating of the events at Littleton. The testate amoebae and plant macrofossil assemblages at Littleton are also highly similar to those identified at Derryville (Caseldine and Gearey 2005) supporting the notion that the proxy signal at Littleton is consistent with a bog burst. If the proxy signal at Littleton is reflecting the bursts at Derryville, $5 \mathrm{~km}$ to the north, and not a similar set of local events, this would imply that the Derryville bog bursts would have been a catastrophe of regional significance. The magnitude of the variability in reconstructed DWT at both sites is similar, which would be surprising if one record were proximal to the location of the bog bursts, and the other several $\mathrm{km}$ away (therefore resulting in different magnitudes reflected in the proxy data). Furthermore, DWT reconstructions from other nearby sites in 
the same interconnected complex of mires, at Longfordpass and Inchirourke (Stastney 2015), do not show a similar sequence of dry-shifts, indicating that whilst the underlying basins are interconnected, the hydrology of the individual areas of ombrotrophic bog were more or less independent; indeed, Casparie (2005) observed just such a situation at Derryville bog, where discrete areas of ombrotrophic peat developed independently.

iv) Bog bursts at Littleton bog - As discussed above, the testate amoebae, plant macrofossil and humification data, as well as the chronological tempo of the events at Littleton are very similar to those associated with bog bursts at Derryville bog (Caseldine and Gearey 2005). Additional supporting evidence for bog bursts at Littleton are provided by the archaeological record: Brindley and Lanting $(1998$, p.55) suggested a bog burst as a possible explanation for the discovery of a trackway (radiocarbon dated to the Iron Age) at a lower elevation than two nearby structures known to be earlier in date (Bronze Age).

iv) Other - Given that the palaeoecological and chronological characteristics of the rapid dry shifts observed at Littleton are consistent with a series of bog burst events, there is at present no need to invoke any other, hitherto unexplained, mechanism. 
For the reasons outlined above, it is concluded that the most likely interpretation of the sudden drying events at Littleton is that they represent a series of local bog bursts. Whilst at Derryville bog burst events could be positively identified with the support of extensive peat stratigraphic mapping and multiple core and column sequences, the similarity in proxy signals between both sites may raise the possibility of developing a set of criteria for the identification of bog bursts from a single core sequence (see section on future work, below).

The decline of Sphagnum austinii Sull. ex Aust at Littleton

The decline of Sphagnum austinii Sull. ex Aust. (formerly S. imbricatum Hornsch. Ex Russ.) has been described as "the most striking vegetation change on the raised bogs of Britain and Northwest Europe during the last 2000 years" (Hughes et al. 2008, p.1033). In common with many raised mires in the British Isles, Sphagnum imbricatum (austinii), a taxon that first occurs in BH6 at c.3930 cal BP (4080-3780 cal BP 95\% confidence) and is a dominant peat component between c.1140-790 cal BP, declines and disappears in the Late Holocene (Barber 1981; Van Geel and Middeldorp 1988; Mauquoy and Barber 1999b; McClymont et al. 2008). Recent investigations (see Hughes et al. 2008) have shown that the contraction in its range shows no uniformity, either temporally or spatially, and several factors have been suggested for the cause of its decline, including climate change (increased bog surface wetness), competition between 
species, an increase in atmospheric inputs, human disturbance of peatlands and genetic erosion (see Swindles et al. 2015).

Following a peak in abundance at $c .890 \mathrm{cal}$ BP (1030-780 cal BP 95\% confidence), S. austinii permanently declines and the final occurrence of the taxon is dated to $530-480$ cal BP (95\% confidence, OxA-33794 450 $\pm 27 \mathrm{BP})$. This timing of this event is similar to that noted elsewhere in the British Isles: although generally not a synchronous event, $S$. austinii typically disappears during the later medieval or pre-industrial modern periods. At several sites this decline is associated with a shift towards wetter conditions (e.g. Mauquoy and Barber 1999b; McClymont et al. 2008), however at Littleton the decline occurs during a period of moderately dry BSW conditions, with testate amoebaederived DWT values rising during the period of decline and immediately after the disappearance. Therefore, at Littleton bog, changes in BSW conditions do not appear to be implicated in the local disappearance of $S$. austinii.

Regional comparisons

Figure 6 shows palaeohydrological proxy data from Littleton presented alongside (a) the 947 year-long reconstruction of the winter North Atlantic Oscillation (NAO) index of Trouet et al. (2009), shown overlain with a smoothed line (span=0.45) in bold, (b) the composite Irish peatland water table record of 
Swindles et al. (2013), and (c) the Northern Britain stacked peatland water table record of Charman et al. (2006); datasets available online via NOAA (https://www.ncdc.noaa.gov/data-access/paleoclimatology-data). Whilst it is important to bear in mind that 'visual' comparisons between different proxy archives can be confounded by chronological uncertainties in turn potentially leading to significant interpretational pitfalls (Baillie 1991; Blaauw 2012), the approach can nevertheless be useful to provide broad contextual frameworks.

Before $c .1300$ cal BP agreement between the proxy data from Littleton bog and the Irish (Swindles et al. 2013) and N. British (Charman et al. 2006) composite water table records is generally poor. Between $c .4000-3700$ cal BP, both the Littleton DWT data and the N. British stacked record show highly variable BSW conditions, although this may be an artefact of non-hydrological factors in the former (see above) and sparse data coverage in the latter; the Irish composite record shows consistently moderate BSW conditions during this period. Both the Irish and N. British records indicate clear wet-shifts at $c .2750$ cal BP, but this is not obviously reflected in either the humification or DWT data from Littleton, although plant macrofossil assemblages do switch to Sphagnum spp. dominance for the first time at $c .2700$ cal BP (2840-2470 cal BP 95\% confidence). Bog bursts B (2650-2300 cal BP 95\% confidence, weighted mean $=2510$ cal BP $)$ and C (1830-1290 cal BP 95\% confidence, weighted mean = 
1540 cal BP) both broadly occur at around the time of marked wet-shifts in both the Irish and N. British composite records.

From c. $1300 \mathrm{cal}$ BP onwards there is good visual agreement between the Littleton DWT data and the Irish composite water table record. The plant macrofossil and humification data also show similar trends to the regional composite water table between $c .1300-730$ cal BP; however both proxies appear to show closer correspondence with the reconstructed winter NAO record, with the low $\mathrm{DHI}$ scores and humification values coinciding with the period of persistently positive NAO during the Medieval Climate Anomaly (MCA), and increasing humification values broadly coinciding with the trend towards a less-positive NAO thereafter. The plant macrofossil data appear to cross a threshold towards assemblages indicative of drier BSW conditions soon after the smoothed line shows a trend towards a less-positive NAO, but before the occurrence of the first negative NAO indicated at $c .500$ cal BP (Trouet et al. 2009).

\section{Drivers of bog bursts at Littleton}

The exact cause of bog burst events is at present uncertain, and a range of both autogenic and allogenic forcing mechanisms have been proposed. Studies focused on modern bog bursts have suggested that sharp increases in effective 
precipitation following prolonged periods of dry conditions appear to have been the proximal cause of bog burst events (Tallis 2001; Dykes and Warburton 2007; Feldmeyer-Christe et al. 2011), although exactly how this hypothesis, based on data resolved at monthly-daily timescales, might be applied to palaeoenvironmental datasets that are probably decadally-resolved at best, is uncertain. Nevertheless, this accords with the suggestion that the bog burst at Bargerveen, Netherlands, at $c .2800$ cal BP, was ultimately climatically-driven (Van Geel et al. 2014). At Littleton, the plant macrofossil DHI scores and, to a lesser extent the humification data, indicate a wet shift immediately prior to bog burst B at $c .2510$ cal BP (95\% confidence $2650-2300$ cal BP), and both this event and bog burst C (1830-1290 cal BP 95\% confidence, weighted mean $=1540 \mathrm{cal}$ BP) do occur at around the time of wet-shifts recorded in composite water table records in the British Isles (Charman et al. 2006; Swindles et al. 2013).

There is less evidence for a climatic driver for bog burst A (3437-2846 cal BP $95 \%$ confidence, weighted mean $=3140 \mathrm{cal}$ BP), although this does occur during a broad period of hemispheric-scale climatic variability, between 3500 2500 cal BP (Mayewski et al. 2004) that would also encompass bog burst B. Both regional composite water table records show drying trends at the time of this bog burst. Bog burst A does, however, occur during a period before fully- 
ombrotrophic conditions are established at the sampling location, and therefore the internal dynamics of the site in relation to the morphology of the bog surface and of the underlying basin may have been at a critical stage at this time (Belyea and Clymo 2001), thus indicating an autogenic driver for this event.

A third causal factor which has been proposed is that disruption caused by human activity, specifically the construction of timber structures on the bog surface, might have been the proximal cause of a bog burst evident at Derryville, just to the north of Littleton bog (Casparie 2001). At Derryville, construction of timber trackways was shown to have blocked localized bog drainage systems, ultimately leading to bursts. An anthropogenic driver for the bog bursts is equally plausible at Littleton, since all three bog bursts occur at around the time that similar timber trackways and platforms were constructed at the site (Brindley and Lanting 1998; Whitaker 2006; Turrell 2008). However, the detailed stratigraphic information required to identify a precise mechanism for any anthropogenic disturbance leading to a bog burst is lacking at Littleton. More widely, there is, at present, little unambiguous evidence for the extent and character of direct human impacts on raised mires during prehistory; future research should address this issue.

On the available evidence from Littleton bog, it is unclear which factors, climatic, autogenic or anthropogenic, either alone or in combination, might have caused 
the bog bursts. The bog bursts at Littleton broadly coincide ( $\pm 150 \mathrm{yrs}$, and thus within the uncertainty limits of the age-depth model) with those at Derryville, which occur at $c .3200$ and $c .2550$, and a further possible burst at 1400 cal BP (Caseldine and Gearey 2005). Given that both sites are situated within the same larger system of wetlands, and that there are close parallels both in terms of date and form between the archaeological structures at both sites, the coincidence of bog bursts at both Derryville and Littleton might plausibly support any of the three main causal factors.

\section{Future work}

Previous studies which have positively identified bog bursts in the palaeoenvironmental record have relied on the collection of substantial amounts of detailed stratigraphic data including the recording of numerous long sections, multiple core sequences, and extensive archaeological survey (Bermingham and Delaney 2006; Gowen et al. 2005). Such extensive studies are, however, rare, and are unlikely to be repeated with any great regularity in the future. The probable identification of bog bursts at Littleton bog, therefore, raises the possibility of developing a set of criteria for the identification of such events from single-core based investigations. Application of these criteria, and testing them against competing explanatory mechanisms, may potentially allow the identification of previously unrecognized bog bursts at other sites, both in 
Ireland and more generally in NW Europe. These criteria should be used to seek potential bog burst signals at other sites since, if they do prove to be more common than previously assumed, this may have significant implications for the interpretation of peatland palaeoclimate records and our understanding of peatland carbon dynamics. At present, however, the most significant 'unknown quantity' is the role of past human impact on raised mires. Although certain activities such as deliberate drainage of peatlands or the cutting of peat during prehistory might not be archaeologically visible, this issue is yet to be explicitly examined. The construction of trackways and other peatland archaeological structures is, however, archaeologically-visible. Whilst previous work has compared the peatland archaeological record of Ireland as a whole with palaeoenvironmental records in order to test environmentally-deterministic models of human-environment relationships at the regional scale (Plunkett et al. 2013), further site-by-site comparison of palaeoenvironmental and archaeological datasets might draw out potentially significant patterns to elucidate the local impact of humans on individual raised mire systems.

\section{Conclusions}

- The multiproxy palaeohydrological record from Littleton bog spans almost the whole of the Late Holocene from c.4140 to after c.170 cal BP. 
- The three proxy datasets display complex relationships reflecting the varying influence of internal bog dynamics and allogenic climatic forcing. A notable example of this complexity is the identification of a series of bog bursts, dated to $c .3140, c .2510$, and $c .1540$ cal BP. These events are characterized by testate amoebae assemblages dominated by Hyalosphenia subflava, plant macrofossil assemblages dominated by monocots, and generally high humification values.

- The driving mechanisms of the bog burst events are uncertain: bog burst A seems to have been linked to the internal dynamics of bog development; however it is possible that the two later bog bursts might have been at least partially climatically-driven. A further complicating factor is the possibility that the construction of prehistoric trackways on the bog surface might have been a proximal driver of the bog burst, as has been suggested at Derryville bog.

- Given that more than 50 bog bursts were recorded in Ireland between 1900 and 2010, it seems likely that these events are at present underreported in the palaeoenvironmental literature. Further work is necessary in order to investigate not only how widespread these events were in the past and what caused them, but also to understand their potentially 
significant implications for peatland palaeoclimate studies and carbon dynamics.

- From c.1300 cal BP, during the MCA, all three proxies show improved agreement, displaying generally good agreement with the Ireland and $\mathrm{N}$. Britain composite water table records. The plant macrofossil and humification datasets in particular show linkages with the 947 year-long winter NAO reconstruction. Such potential linkages suggest that longer proxy reconstructions of winter NAO should be sought, in order to examine the relationship between peatland hydrology and changes in atmospheric circulation for the Middle and Late Holocene.

- The disappearance of Sphagnum austinii at Littleton bog is dated to 530480 cal BP and occurs during a period of moderately dry BSW conditions, suggesting non-climatic factors are likely to have been the dominant cause of the local decline.

\section{Acknowledgements}

The authors gratefully acknowledge and thank Bord na Móna and ADS Ltd (Ireland) for access to the study site. Three dates were provided by the NERC radiocarbon dating facility (Project ID NF/2015/1/23 awarded to NPB). PS was supported by a PhD studentship funded by SAGES (formerly SHES) and 
QUEST, University of Reading. The authors are grateful to the two anonymous reviewers for their helpful and constructive comments which helped improve this manuscript.

\section{References}

Amesbury MJ, Swindles GT, Bobrov A, Charman DJ, Holden J, Lamentowicz M, Mallon G, Mazei Y, Mitchell EAD, Payne RJ, Roland TP, Turner TE and Warner BG (2016) Development of a new pan-European testate amoeba transfer function for reconstructing peatland palaeohydrology. Quaternary Science Reviews 152: 132-151.

Baillie MGL (1991) Suck-in and smear - two related chronological problems for the 90s. Journal of Theoretical Archaeology 2: 12-16.

Barber KE (1981) Peat Stratigraphy and Climatic Change: A Paleoecological Test of the Theory of Cyclic Peat Bog Regeneration. Rotterdam: Balkema.

Barber KE, Chambers FM, Maddy D, Stoneman R and Brew JS (1994) A sensitive high-resolution record of late Holocene climatic change from a raised bog in northern England. The Holocene 4(2): 198-205. 
Barber KE, Chambers FM and Maddy D. (2004) Late Holocene climatic history of northern Germany and Denmark: peat macrofossil investigations at Dosenmoor, Schleswig-Holstein, and Svanemose, Jutland. Boreas 33(2): 132144.

Barber KE and Charman DJ (2003) Holocene palaeoclimate records from peatlands. In: Mackay A, Battarbee RW, Birks J and Oldfield F (eds) Global Change in the Holocene. London: Arnold, pp.210-226.

Barber KE, Maddy D, Rose N, Stevenson AC, Stoneman R and Thompson R (2000) Replicated proxy-climate signals over the last $2000 \mathrm{yr}$ from two distant UK peat bogs: new evidence for regional palaeoclimate teleconnections. Quaternary Science Reviews 19(6): 481-487.

Belyea LR and Clymo RS (2001) Feedback control of the rate of peat formation. Proceedings of the Royal Society B: Biological Sciences 268(1473): 13151321.

Bermingham NC and Delaney M (eds) (2006) The Bog Body of Tumbeagh. Bray: Wordwell.

Blaauw M (2012) Out of tune: the dangers of aligning proxy archives. Quaternary Science Reviews 36: 38-49. 
Blaauw M and Christen JA (2011) Flexible Paleoclimate Age-Depth Models Using an Autoregressive Gamma Process. Bayesian Analysis 6(3): 457-474.

Blaauw M, Christen JA, Mauquoy D, van der Plicht J and Bennett KD (2007) Testing the timing of radiocarbon-dated events between proxy archives. The Holocene 17(2): 283-288.

Blackford JJ (2000) Palaeoclimatic records from peat bogs. Trends in Ecology \& Evolution 15(5): 193-198.

Blackford JJ and Chambers FM (1993) Determining the degree of peat decomposition for peat-based palaeoclimatic studies. International Peat Journal 5: 7-24.

Bond G, Kromer B, Beer J, Muscheler R, Evans M, Showers W, Hoffman S, Lotti-Bond R, Hajdas I and Bonani G (2001) Persistent Solar Influence on North Atlantic Climate During the Holocene. Science 294(5549): 2130-2136.

Brindley AL and Lanting JN (1998) Radiocarbon dates for Irish trackways. Journal of Irish Archaeology 9: 45-67.

Caseldine C and Gearey B (2005) A multiproxy approach to reconstructing surface wetness changes and prehistoric bog bursts in a raised mire system at Derryville Bog, Co. Tipperary, Ireland. The Holocene 15(4): 585 -601. 
Casparie W (2001) Prehistoric building disasters in Derryville Bog, Ireland: Trackways, Floodings and Erosion. In Raftery B and Hickey J (eds) Recent Developments in Wetland Research. Dublin: University College Dublin, pp.115128.

Casparie W (2005) Peat morphology and bog development. In Gowen M, O'Neill J and Phillips M (eds) The Lisheen Mine Archaeological Project 19961998. Bray: Wordwell, pp.13-54.

Casparie W (2006) Tumbeagh Bog, Co. Offaly, an extremely wet landscape: 7500 years of peat growth reconstructed. In Bermingham NC and Delaney M (eds) The Bog Body of Tumbeagh. Bray: Wordwell, p.119-154.

Casparie W and Gowen M (2005) Geology and topography. In Gowen M, O'Neill J and Phillips M (eds) The Lisheen Mine Archaeological Project 19961998. Bray: Wordwell, pp.11-12.

Chambers FM, Beilman DW and Yu Z (2010) Methods for determining peat humification and for quantifying peat bulk density, organic matter and carbon content for palaeostudies of climate and peatland carbon dynamics. Mires and Peat 7(Article 07): 1-10. 
Charman DJ (2010) Centennial climate variability in the British Isles during the mid-late Holocene. Quaternary Science Reviews 29(13-14): 1539-1554.

Charman DJ, Barber KE, Blaauw M, Langdon PG, Mauquoy D, Daley TJ, Hughes PDM, Karofeld E (2009) Climate drivers for peatland palaeoclimate records. Quaternary Science Reviews 28(19-20): 1811-1819.

Charman DJ, Blundell A, Chiverrell RC, Hendon D and Langdon PG (2006) Compilation of non-annually resolved Holocene proxy climate records: stacked Holocene peatland palaeo-water table reconstructions from northern Britain. Quaternary Science Reviews 25(3-4): 336-350.

Charman DJ, Hendon D and Woodland WA (2000) The Identification of Testate Amoebae (Protozoa:Rhizopoda) in Peats. Technical Guide 9. London: Quaternary Research Association.

Corbet SA (1973) An Illustrated Introduction to the Testate Rhizopods in Sphagnum, with Special Reference to the Area Around Malham Tarn, Yorkshire. Field Studies 3: 801-838.

Daley TJ and Barber KE (2012) Multi-proxy Holocene palaeoclimate records from Walton Moss, northern England and Dosenmoor, northern Germany, 
assessed using three statistical approaches. Quaternary International 268: 111127.

Daniels RE and Eddy A (1985) Handbook of European Sphagna. Huntingdon: Institute of Terrestrial Ecology.

Dupont LM (1986) Temperature and rainfall variations in the Holocene based on comparative palaeoecology and isotope geology of a hummock and hollow (Bourtangerveen, The Netherlands). Review of Palaeobotany and Palynology 48: 71-159.

Dykes AP and Warburton J (2007) Mass movements in peat: A formal classification scheme. Geomorphology 86(1-2): 73-93.

Feehan J, O'Donovan G (1996) The Bogs of Ireland. Dublin: University College Dublin.

Feldmeyer-Christe E, Küchler M and Wildi O (2011) Patterns of early succession on bare peat in a Swiss mire after a bog burst. Journal of Vegetation Science 22(5): 943-954.

Van Geel B, Buurman J and Waterbolk HT (1996) Archaeological and palaeoecological indications of an abrupt climate change in The Netherlands, 
and evidence for climatological teleconnections around 2650 BP. Journal of Quaternary Science 11(6): 451-460.

Van Geel B, Heijnis H, Charman DJ, Thompson G and Engels S (2014) Bog burst in the eastern Netherlands triggered by the $2.8 \mathrm{kyr}$ BP climate event. The Holocene 24(11): 1465-1477.

Gomaa F, Mitchell EAD and Lara E (2013) Amphitremida (Poche, 1913) Is a New Major, Ubiquitous Labyrinthulomycete Clade. PLoS ONE 8(1): e53046.

Gowen M, O'Neill J and Phillips M (2005) The Lisheen Mine Archaeological Project 1996-8. Bray: Wordwell.

Haslam SM (1972) Biological flora of the British Isles. No. 128 Phragmites communis Trin. (Arundo phragmites L., ?Phragmites australis (Cav.) Trin.). Journal of Ecology 60: 585-610.

Hill MO (1976) A key for the identification of British Sphagna using macroscopic characters. Journal of the British Bryological Society 27: 22-31.

Hill MO (1988) Sphagnum imbricatum ssp. austinii (Sull.) Flatberg and ssp. affine (Ren. \&amp; Card.) Flatberg in Britain and Ireland. Journal of Bryology 15(1): 109-115. 
Hill MO, Hodgetts NG and Payne AG (1992) Sphagnum: A Field Guide.

Peterborough: The UK Joint Nature Conservation Committee.

Hughes PDM and Barber KE (2004) Contrasting pathways to ombrotrophy in three raised bogs from Ireland and Cumbria, England. The Holocene 14(1): 6577.

Kershaw AP (1997) A modification of the Troels-Smith system of sediment description and portrayal. Quaternary Australia 15(2): 63-68.

Kiely G, Leahy P, Ludlow F, Stefanini B, Reilly E, Monk M and Harris J (2010) Extreme Weather, Climate and Natural Disasters in Ireland. CCRP Report 5, EPA Climate Change Research Programme. Cork: University College Cork.

Langdon PG, Brown AG, Caseldine CJ, Blockley SPE and Stuijts I (2013) Corrigendum to "Regional climate change from peat stratigraphy for the mid- to late Holocene in central Ireland" [Quat. Int. 268 (2012) 145-155]. Quaternary International 296: 253.

Lehman SJ and Keigwin LD (1992) Sudden changes in North Atlantic circulation during the last deglaciation. Nature 356(6372): 757-762.

Line JM, Ter Braak CJ and Birks HJB (1994) WACALIB version 3.3 - a computer program to reconstruct environmental variables from fossil 
assemblages by weighted averaging and to derive sample specific errors of prediction. Journal of Paleolimnology 10: 147-152.

Magurran AE (1988) Ecological Diversity and Its Measurement. Princeton: Princeton University Press.

Mauquoy D and Barber, KE (1999a) A replicated 3000 yr proxy-climate record from Coom Rigg Moss and Felecia Moss, the Border Mires, northern England. Journal of Quaternary Science 14(3): 263-275.

Mauquoy D and Barber KE (1999b) Evidence for climatic deteriorations associated with the decline of Sphagnum imbricatum Hornsch. ex Russ. in six ombrotrophic mires from northern England and the Scottish Borders. The Holocene 9(4): 423-437.

Mauquoy D and van Geel B (2007) Mire and peat macros. In Elias S (ed) Encyclopedia of Quaternary Science. Amsterdam: Elsevier, pp.2315-2336. Mauquoy D, Yeloff D, van Geel B, Charman DJ and Blundell A (2008) Two decadally resolved records from north-west European peat bogs show rapid climate changes associated with solar variability during the mid-late Holocene. Journal of Quaternary Science 23: 745-763. 
Mayewski P, Rohling E, Curt Stager J, Karlen W, Maasch K, Meeker L, Meyerson E, Gasse F, van Kreveld S, Holmgren K, Lee-Thorp J, Rosqvist G, Rack F, Staubwasser M, Schneider R and Steig E (2004) Holocene climate variability. Quaternary Research 62(3): 243-255.

McClymont EL, Mauquoy D, Yeloff D, Broekens P, van Geel B, Charman DJ, Pancost RD, Chambers FM and Evershed RP (2008) The disappearance of Sphagnum imbricatum from Butterburn Flow, UK. The Holocene 18(6): $991-$ 1002.

McMullen JA, Barber KE and Johnson B (2004) A palaeoecological perspective of vegetation succession on raised bog microforms. Ecological Monographs 74(1): 45-77.

Met Éireann (2012) Monthly Data. Available at: www.met.ie/climate/monthlydata.asp?Num=1975 (accessed 4 January 2013).

Mitchell GF (1956) Post-Boreal pollen diagrams from Irish raised bogs. Proceedings of the Royal Irish Academy Section B 57: 185-251.

Mitchell GF (1965) Littleton bog, Tipperary: an Irish agricultural record. The Journal of the Royal Society of Antiquaries of Ireland 95(1): 121-132. 
Mitchell GF (1981) The Base of the Littletonian (Holocene) in Ireland. Journal of Earth Sciences 4(2): 97-100.

Morris PJ, Baird AJ, Young DM and Swindles GT (2015) Untangling climate signals from autogenic changes in long-term peatland development.

Geophysical Research Letters 42(24): 10788-10797.

Morris PJ, Belyea LR and Baird AJ (2011) Ecohydrological feedbacks in peatland development: A theoretical modelling study. Journal of Ecology 99: $1190-1201$.

National Monuments Service (2013) Peatland Review 2013: Review of Archaeological Survey and Mitigation Policy Relating to Bord Na Mona Peatlands Since 1990. Dublin: Department of the Arts, Heritage and the Gaeltacht.

Ogden CG and Hedley RH (1981) An Atlas of Freshwater Testate Amoebae. London: Oxford University Press.

Payne RJ (2010) Can testate amoeba-based palaeohydrology be extended to fens? Journal of Quaternary Science 26(1): 15-27. 
Payne RJ and Blackford JJ (2008) Peat humification and climate change: a multi-site comparison from mires in south-east Alaska. Mires and Peat 3(Article 09): 1-11.

Plunkett G (2006) Tephra-linked peat humification records from Irish ombrotrophic bogs question nature of solar forcing at $850 \mathrm{cal}$. yr BC. Journal of Quaternary Science 21(1): 9-16.

Plunkett G, McDermott C, Swindles GT and Brown DM (2013) Evironmental indifference? A critique of environmentally deterministic theories of peatland archaeological site construction in Ireland. Quaternary Science Reviews 61, 1731.

R Core Team (2013) R: A Language and Environment for Statistical Computing. Vienna: R Foundation for Statistical Computing. Available at: www.R-project.org/.

Reimer P, Bard E, Bayliss A, Beck JW, Blackwell PG, Bronk Ramsey C, Buck CE, Cheng H, Edwards RL, Friedrich M, Grootes P, Guilderson TP, Hafidason H, Hajdas I, Hatte C, Heaton TJ, Hoffman DL, Hogg AG, Hughen KA, Kaiser KF, Kromer B, Manning SW, Niu M, Reimer RW, Richards DA, Scott EA, Southon JR, Staff R, Turney CSM and van der Plicht J (2013) IntCal13 and 
Marine13 Radiocarbon Age Calibration Curves 0-50,000 Years cal BP. Radiocarbon 55(4): 1869-1887.

Roland TP, Caseldine CJ, Charman DJ, Turney CSM and Amesbury MJ (2014) Was there a "4.2 ka event" in Great Britain and Ireland? Evidence from the peatland record. Quaternary Science Reviews 83: 11-27.

Roland TP, Daley TJ, Caseldine CJ, Charman DJ, Turney CSM, Amesbury MJ, Thompson GJ and Woodley EJ (2015) The 5.2 ka climate event: Evidence from stable isotope and multi-proxy palaeoecological peatland records in Ireland. Quaternary Science Reviews 124: 209-223.

Stastney P (2015) Examining the relationships between Holocene climate change, hydrology and human society in Ireland. PhD Thesis, University of Reading, UK.

Swindles GT, Blundell A, Roe HM and Hall VA (2010) A 4500-year proxy climate record from peatlands in the North of Ireland: the identification of widespread summer "drought phases"? Quaternary Science Reviews 29: 15771589.

Swindles GT, Lawson IT, Matthews I, Blaauw M, Daley TJ, Charman DJ, Roland T, Plunkett G, Schettler G, Gearey B, Turner TE, Blundell A, Rea HA, 
Amesbury MJ, Barber K, Blackford JJ, Branch NP, Chambers FM, Holmes J, Langdon PG, Maddy D, McCarroll J, McDermott F, Mitchell FJG, Oksanen P, Pritchard O, Stastney P, Stefanini B, Young DS, Roe HM, Wheeler J, Becker K and Armit I (2013) Centennial-scale climate change in Ireland during the Holocene. Earth Science Reviews 126: 300-320.

Swindles GT, Morris PJ, Baird AJ, Blaauw M and Plunkett G (2012) Ecohydrological feedbacks confound peat-based climate reconstructions. Geophysical Research Letters 39(11): L11401.

Swindles GT, Plunkett G and Roe HM (2007) A delayed climatic response to solar forcing at 2800 cal. BP: multiproxy evidence from three Irish peatlands. The Holocene 17(2): 177-182.

Swindles GT and Roe HM (2007) Examining the dissolution characteristics of testate amoebae (Protozoa: Rhizopoda) in low pH conditions: Implications for peatland palaeoclimate studies. Palaeogeography, Palaeoclimatology, Palaeoecology 252(3-4): 486-496.

Swindles GT, Turner TE, Roe HM, Hall VA and Rea HA (2015) Testing the cause of the Sphagnum austinii (Sull. ex Aust.) decline: Multiproxy evidence from a raised bog in Northern Ireland. Review of Palaeobotany and Palynology 213: 17-26. 
Tallis J (2001) Bog bursts. Biologist 48(5): 218-223.

Telford RJ and Birks HJB (2005) The secret assumption of transfer functions: problems with spatial autocorrelation in evaluating model performance. Quaternary Science Reviews 24(20-21): 2173-2179.

Telford RJ and Birks HJB (2011a) A novel method for assessing the statistical significance of quantitative reconstructions inferred from biotic assemblages. Quaternary Science Reviews 30(9-10): 1272-1278.

Telford RJ and Birks HJB (2011b) Effect of uneven sampling along an environmental gradient on transfer-function performance. Journal of Paleolimnology 46(1): 99-106.

Troels-Smith J (1955) Karakterisering af lose jordarter. Geological survey of Denmark 3(10): 1-73.

Trouet V, Esper J, Graham NE, Baker A, Scourse JD and Frank DC (2009) Persistent Positive North Atlantic Oscillation Mode Dominated the Medieval Climate Anomaly. Science 324(5923): 78-80.

Turrell S (2008) Excavations in Littleton Bog, Co. Tipperary for Bord Na Móna Ltd. Unpublished report, Archaeological Development Services Ltd., Kells, Ireland. 
Whitaker J (2006) Tipperary 2006:1840. Available at:

www.excavations.ie/Pages/Details.php?Year=\&County=Tipperary\&id=16642 (accessed 20 Jun 2013).

Yeloff D and Mauquoy D (2006) The influence of vegetation composition on peat humification: implications for palaeoclimatic studies. Boreas 35(4): 662 673. 

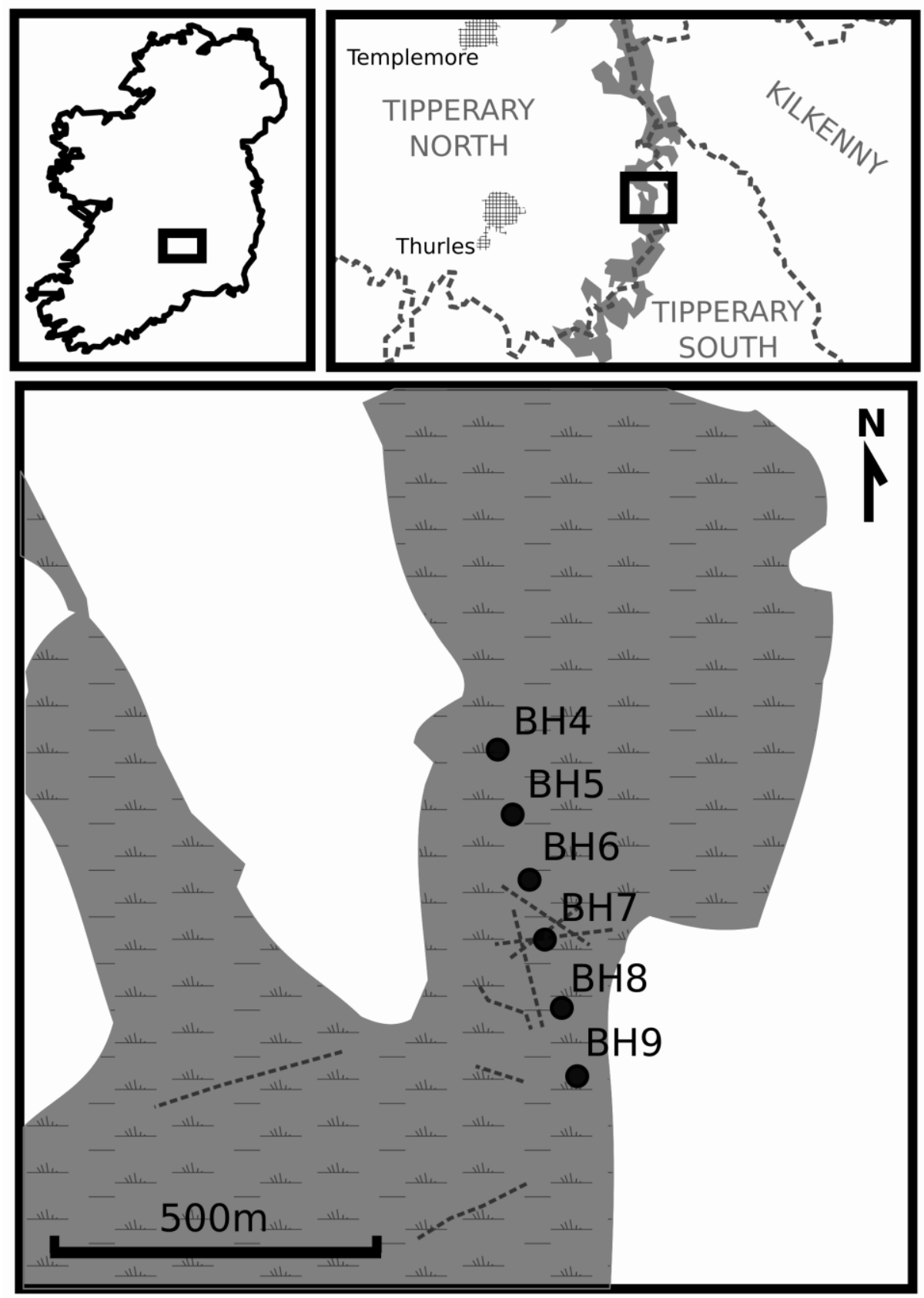

Figure 1: Site location. Shaded areas indicate areas of raised mire and milled production bogs. In the lower panel, the location of the boreholes transect is marked by the black circles and known extent of archaeological trackways are marked by dashed lines. 


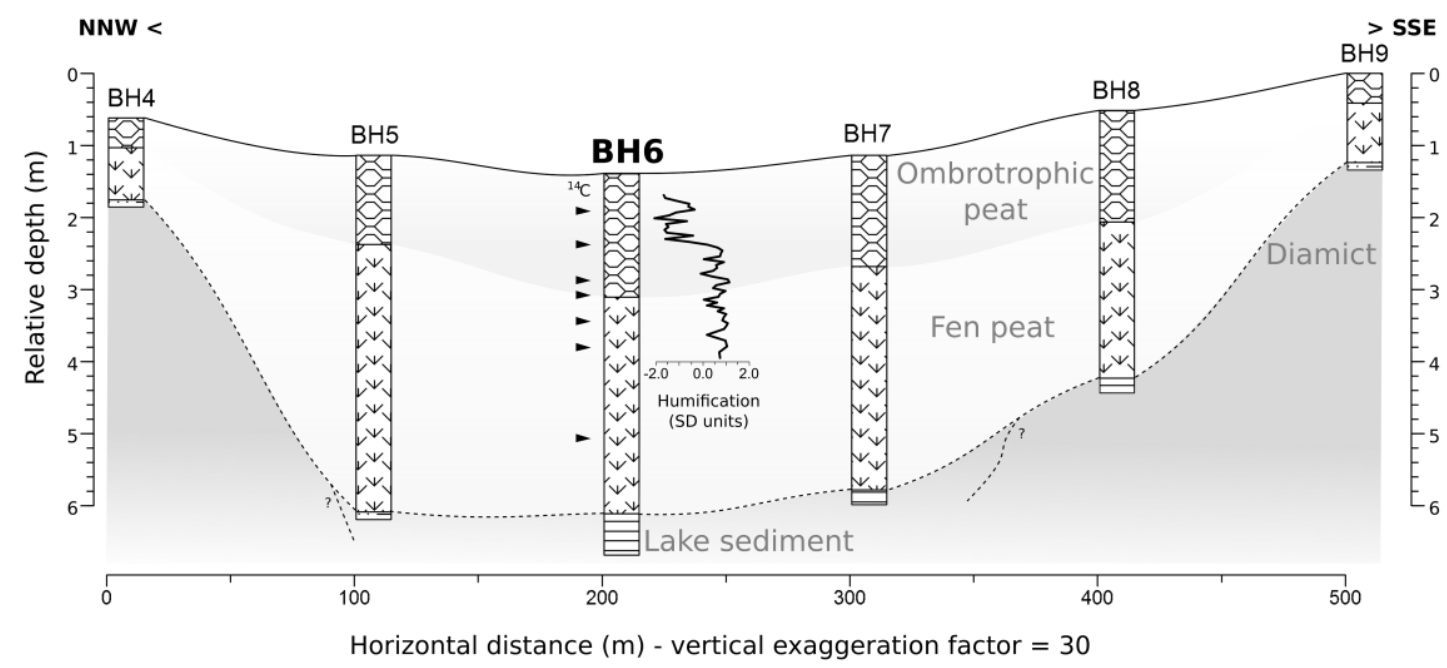

Figure 2: Stratigraphic cross section of Littleton bog. Sampling depths for radiocarbon dating are indicated by the triangles to the left of $\mathrm{BH} 6$, the humification curve is plotted to the right. 


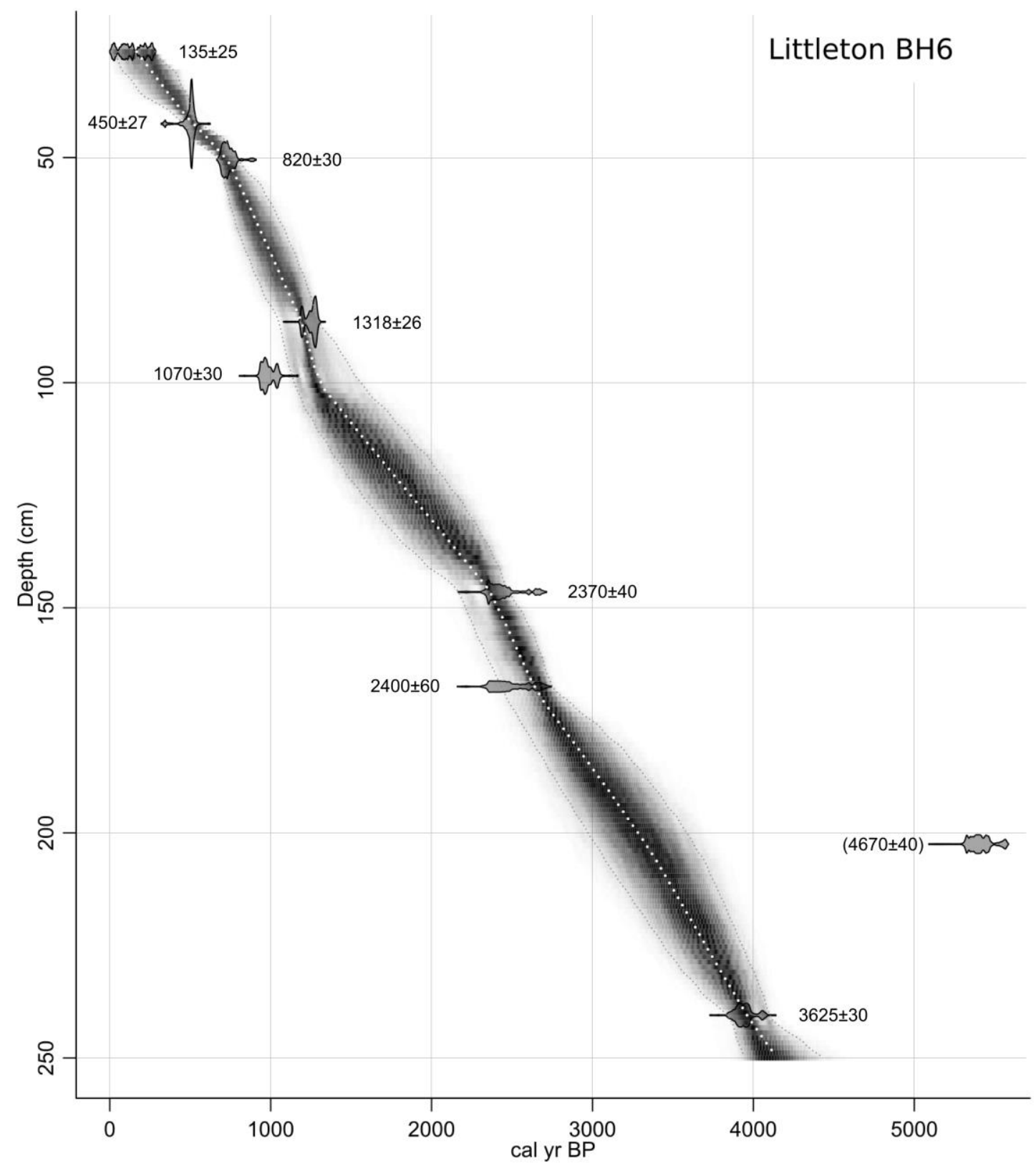

Figure 3: Age vs depth model. Note that only the section of core analyzed, to a depth of $250 \mathrm{~cm}$ bgs, is shown. 


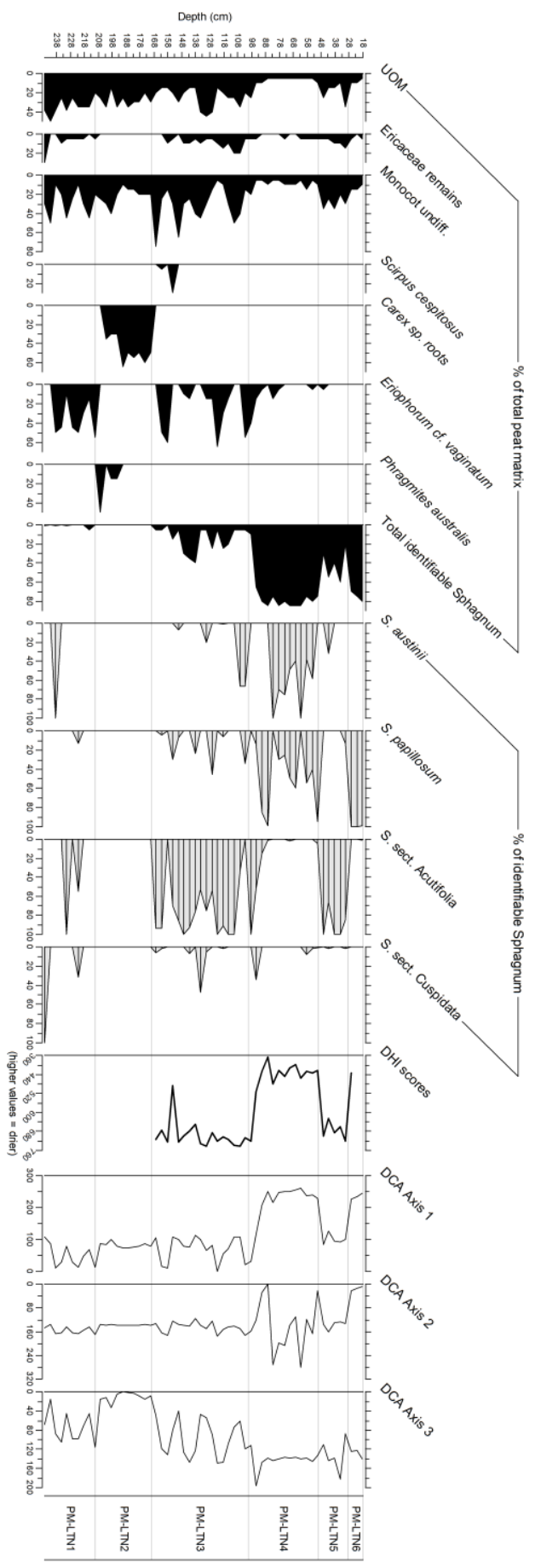

Figure 4: Plant macrofossil diagram, BH6 Littleton bog. 


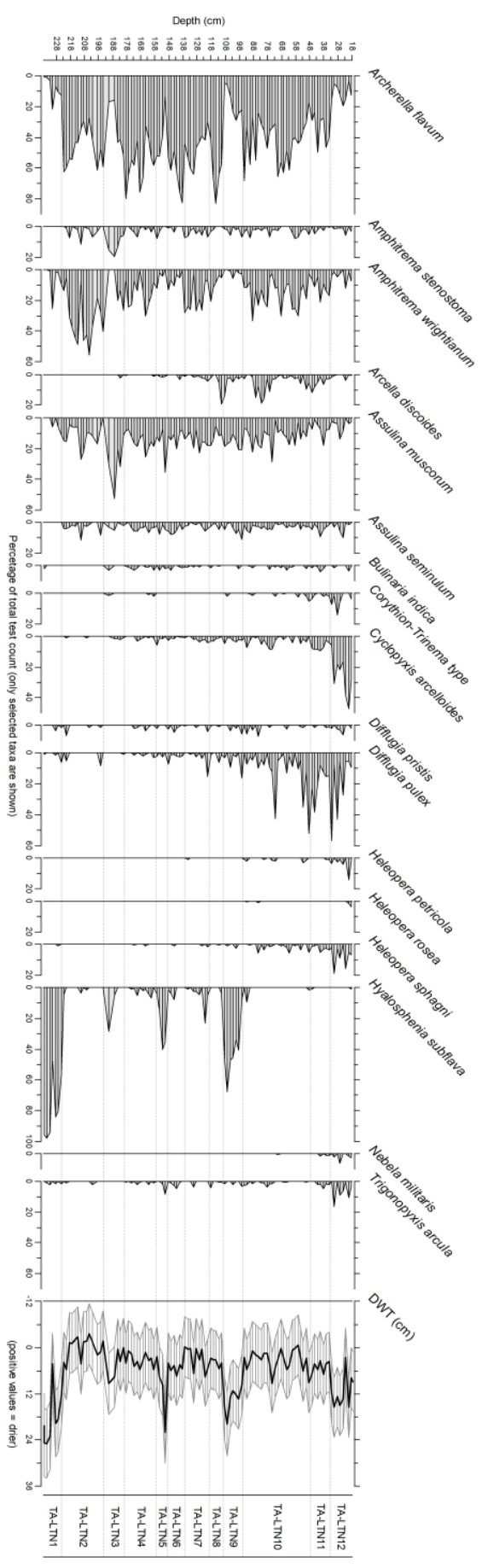

Figure 5: Testate amoebae diagram, BH6 Littleton bog. Only main taxa are shown. 


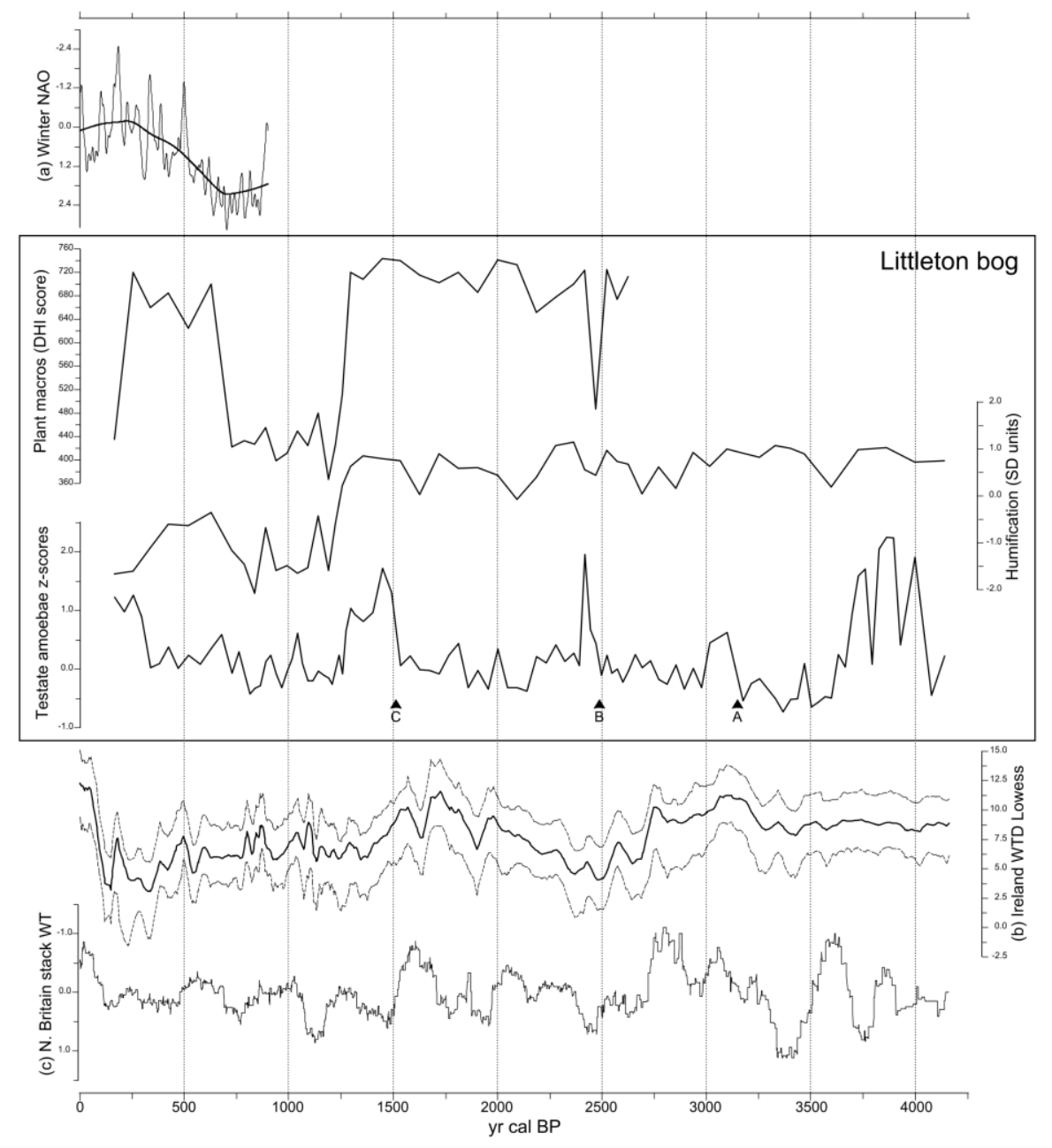

Figure 6: Comparison of data from Littleton bog with other proxy records. In box: BH6 Littleton bog - top, plant macrofossil DHI scores; middle, standardized humification values; bottom, testate amoebae-derived DWT z-scores, with bog bursts A, B and C labelled. Above box: (a) reconstructed winter NAO index values (Trouet et al. 2009), shown with a bold smooth line (span=0.45). Below box: (b) composite Irish peatland water table WTD Lowess (Swindles et al. 2013); and (c) Northern Britain stacked water table (Charman et al. 2006). 